\title{
İlkokul 2. 3. ve 4. Sınıf Öğrencilerinin Yazma Becerilerinin İncelenmesi*
}

\section{$\operatorname{Ramazan~TOK}^{* *}$, Özge ERDOĞAN***}

Öz: Bu araştırmada ilkokul 2. 3. ve 4. sınıf öğrencilerinin yazma becerilerinin incelenmesi amaçlanmıştır. Araştırmada betimsel türde tarama modeli kullanılmıştır. Araştırma Trabzon il merkezindeki üç ilkokulda basit olasılıklı (rastgele) örnekleme yolu ile belirlenen 436 öğrenci ile yürütülmüştür. Elde edilen veriler, "Çok Boyutlu Okunaklılık Ölçeği" ve "Yazılı Anlatımı Değerlendirme İçin Dereceli Puanlama Anahtarı" ile değerlendirilmiştir. Araştırma sonucunda öğrencilerin yazı okunaklılığının orta düzeyde, 2. ve 3. sınıf öğrencilerinin yazılı anlatım becerilerinin orta düzey, 4. sınıf öğrencilerinin yazılı anlatım becerilerinin ise iyi düzeyde olduğu ortaya konmuştur. Ayrıca yazı okunaklılığında sınıflar arasında anlamlı bir farkın olmadığı, yazılı anlatım becerilerinde ise sınıflar arasında anlamlı bir fark olduğu sonucuna ulaşılmıştır. Çalışmada öğrencilerin yazma becerilerinin geliştirilmesi için, mekanik yazma becerileri ile ilgili çalışmaların yapılması ve yazma becerilerini etkileyen değişkenlerle ilgili araştırmalar yapılması önerilmektedir.

Anahtar Kelimeler: Yazma, Yazma Becerileri, Yazma Gelişimi.

\section{Investigating the Primary School 2nd, 3rd and 4th Grade Students' Skills of Writing}

Abstract: This research aims to investigate the skills of writing in 2nd, 3rd and 4th grade primary school students. In the work, scanning model in descriptive type is used. The research was done in three primary school in Trabzon. The research was gone through with 436 students determined by simple probability (random) sampling method. The research data

\footnotetext{
* "İlkokul 2. 3. ve 4. Sınıf Öğrencilerinin Yazma Becerilerinin İncelenmesi" başlıklı yüksek lisans tezinden hazırlanmıştır.

** Sınıf Öğretmeni, Kovanlıköy İlkokulu, Çarşıbaşı, TRABZON. rtok2007@ hotmail.com

** Yrd. Doç. Dr. Karadeniz Teknik Üniversitesi, Eğitim Fakültesi, İlköğretim Bölümü. erdoganozge.edu@gmail.com 
was evaluated using "Multi Dimension Illegibility Scale" and "Written Expression Rubric". As a result of the research, it was found that their font legibility is at an intermediate level. It was found that $2^{\text {nd }}$ and $3^{\text {rd }}$ class writing skills are middle level, $4^{\text {th }}$ class writing skills are at good level. It was concluded that there was no significant difference in font legibility, but there was a significant difference in writing skills between classes. In the study, to improve student's writing skills, it is suggested that works related with mechanical writing skills and researches about the variables influencing writing skills should be done.

Key Words: Writing, Writing Skills, Improvement of Writing.

\section{Giriş}

Anlama, düşünme ve başkalarının yazılı fikirleri ile iletişim kurma, sadece okul döneminde değil hayatın her döneminde gerekli olan becerilerdir. $\mathrm{Bu}$ becerilerin kazanılmasında ve geliştirilmesinde okuryazarlık becerilerinden biri olan yazma becerisi oldukça önemli bir rol oynar (Erdoğan, 2012). Ancak yazma, öğrencilerin en çok zorlandıkları ve geliştirilmesi en zor olan dil becerisidir (Albertson ve Billingsley, 2000; Olinghouse ve Santangelo, 2010). Çünkü yazma sürecinde yazarın, duygu ve düşüncelerini etkili bir şekilde ifade etmek ve okuyucuya anlamlı bir mesaj vermek için birçok bilişsel işlemi koordineli bir şekilde gerçekleştirmesi gerekir (Flowers ve Hayes, 1981). Bu bakımdan yazma bir takım süreç ve stratejileri gerektiren karmaşık bilişsel bir etkinliktir (Chien, 2010).

Prior (2006), yazma sürecini yazar ve okuyucu arasında anlam kurulan, aktarılmak istenen düşüncenin yapılandırılarak kâğıda açık ve doğru bir biçimde aktarılmasını gerektiren etkileşimli bir süreç olarak tanımlar. Bu yazılı anlatım süreci, düşüncenin yazıya dönüşmesi, düşünceyi karşılayacak olan sözcüklerin yan yana gelmesi ve bunu iletecek bir biçimde düzenlenmesi ile başlar (Kuvanç, 2008). Moore'a (2009) göre düşüncelerin yazıya aktarılma 
sürecinde yazarın, bir yandan okuyucuya mesajını en iyi nasıl vereceğini düşünmesi gerekir. Çünkü yazma ve düşünme birbiriyle yakından ilişsilidir (Bearne, 2002). Duygu ve düşüncelerin kâğıda yazılı olarak aktarılması; düşünme, anlama ve anlatma becerilerinin ortak bir ürünüdür (Archibald, 2010; Thornton, 2010; Wang, 2012). Yeterli düzeyde yazılı anlatım becerisine sahip öğrenciler, zihinde yapılandırdıkları duygu ve düşünceleri yazım ve dil bilgisi kurallarına uygun bir şekilde kâğıda aktarabilirler. Ancak yeterli yazılı anlatım becerilerine sahip olamayan öğrenciler ise, kendi fikirlerini ve bilgilerini yazıya istenen şekilde aktaramazlar (Zampardo, 2008).

Nitelikli bir yazma öğretim süreci, hem öğrencilerin yazılı anlatım becerilerinin geliştirilmesi hem de okunaklı yazılar yazması üzerine odaklanır. Çünkü yazma, bilişsel süreçler gerektiren bir beceri olmasının yanında, yapılandırılmış düşüncelerin kâğıda aktarılmasına yardımcı olacak motor becerilerin koordinasyonunu da içermektedir. Ortaya koyulan yazılı anlatım ürünün duygu ve düşünceleri etkili bir şekilde aktarması yazının içerik boyutu ile ilgilidir. Bununla birlikte yazının okunaklı olması ise biçimsel yönü ile ilgilidir.

Rosenblum, Weiss ve Parush (2003), öğrencilere hem içerik yönünden nitelikli hem de biçimsel yönden okunaklı yazılar yazmayı öğretmek gerektiğini ifade eder. Çünkü yazma becerisinin, akademik performansı etkilemesi muhtemeldir (Calp, 2013). Bu durum öğrencilerin içerik olarak iyi organize edilmiş, biçimsel olarak da okunaklı olan yazılı ürünler oluşturmalarını gerekli kılmaktadır (Yıldız, 2013). Graham'a (2010) göre nitelikli bir yazma öğretimi için, okunaklı ve düzgün bir yazı vazgeçilmez bir unsurdur.

Yazının biçimsel özellikleriyle ilgili bir kavram olan okunaklılık, yazma becerilerinin gelişimi için önemli ölçüt olarak kabul edilir (Brailsford ve Stead, 2007; Fountas ve Pinnell, 
2009; Graham, 2010; Ziviani ve Watson-Will, 1998). Okunaklılık, harflerin kâğıt üzerinde uygun ölçütlerde yazılması, doğru eğime sahip olması, harfler ve kelimeler arasındaki boşluğun doğru ayarlanması, satır çizgisi hizasında yazılması, harfler arasındaki bağlantıların, alt ve üst uzantıların doğru yönde yapılması gibi fiziksel özellikleri inceler (Graham ve Miller, 1980; Graham, Berninger ve Weintraub, 1998; Tseng ve Chow, 2000; Zachry ve Doan, 2016). Harflerin biçimi, boyutu, eğimi, boşluğu ve satır çizgisi üzerinde yazılması ile ilgili olan okunaklılık, yazma öğretim sürecinin yazılı anlatım ile birlikte geliştirilmesi gereken önemli bir öğesidir.

İlkokul birinci sınıfta gerçekleştirilen yazı çalışmalarında öğrencilerden hem harfleri doğru ve okunaklı yazmaları hem de seviyelerine uygun yazılı ürünler ortaya koymaları beklenmektedir. Ünalan'a (2001) göre ilkokul birinci sınıfta yazı çalışmalarında birinci amaç, harflerin özelliklerini, yazılış biçim ve yönünü, bağlanışını kavratmak; ikinci amaç da sınıf seviyesine uygun hızda yazı esnekliğini kazandırmaktır. Bununla beraber ilkokul birinci sınıftan sonra ise öğrenciler yazılarında duygu ve düşüncelerini anlamlı cümlelerle anlatabilecek yazılı anlatım becerisine sahip olmalıdırlar (Demirel ve Şahinel, 2006). Başka bir ifadeyle ilkokul birinci sınıftan itibaren öğrencilerin yazılarının okunaklılık ve yazılı anlatım açısından geliştirilmesi önem kazanmaktadır. Buradan hareketle bu araştırmada 2. 3. ve 4. sınıf öğrencilerinin yazma becerilerine ilişkin gelişimlerinin hem yazılı anlatım hem de okunaklılık açısından incelenmesi amaçlanmıştır. Yazma becerisine ilişkin yapılan araştırmalar, genel olarak öğrencilerin yazma becerilerini artırmaya yönelik deneysel çalışmalar üzerine yoğunlaştığını göstermektedir. İlkokul öğrencilerinin yazma becerilerini bütünüyle ele alan çalışmaların sayısı ise oldukça azdır. Öğrencilerin yazma becerilerine ilişkin gelişimleri incelenerek, yazma becerilerinin ne düzeyde olduğu ortaya koyulmalı ve gelişim düzeyine göre çeşitli çalışmalar yapılmalıdır. Bu çalışma, öğrencilerin sınıf 
seviyelerine göre yazma becerilerinin ne düzeyde olduğunu ortaya koyması bakımından önem arz etmektedir. Bununla birlikte yazma becerisini iki boyutlu olarak ölçmesi ve sinıflar arasındaki gelişimi belirlemesi açısından da önemlidir. Buradan hareketle yapılan araştırmanın amacı, ilkokul 2, 3 ve 4. sınıf öğrencilerinin yazma becerilerini okunaklılık ve yazılı anlatım açısından incelenmektir. Araştırmada bu amaca ulaşmak için aşağıdaki sorulara yanıt aranmıştır:

1. İlkokul 2. 3. ve 4. sınıf öğrencilerinin yazıları okunaklılık açısından ne düzeydedir?

2. İlkokul 2. 3. ve 4. sınıf öğrencilerinin yazılı anlatım becerileri ne düzeydedir?

3. İlkokul 2. 3. ve 4. sınıf öğrencilerinin yazı okunaklılı̆̆ı sınıf düzeylerine göre farklılaşmakta mıdır?

4. İlkokul 2. 3. ve 4. sınıf öğrencilerinin yazılı anlatım becerileri sınıf düzeylerine göre farklılaşmakta mıdır?

\section{Yöntem}

Araştırmanın Modeli: $\mathrm{Bu}$ araştırmada mevcut durumu olduğu gibi açılamaya çalışan betimsel türde tarama modeli kullanılmıştır. "Tarama modelleri, geçmişte ya da halen var olan bir durumu olduğu gibi betimlemeyi amaçlayan araştırma yaklaşımlarıdır. Tarama yönteminde araştırmaya konu olan olay, birey ya da nesne, kendi koşulları içinde ve olduğu gibi tanımlanmaya çalışılır. Onları, herhangi bir şekilde değiştirme, etkileme çabası gösterilmez. Bilinmek istenen şey vardır ve oradadır.” (Karasar, 2014, s.77). Tarama modeliyle yapılan çalışmalarda evrenin özellikleri hem araştırma sorularını, hem örneklem seçimini hem de araştırmanın 
yürütülmesi için kullanılması gereken kaynakların neler olacağını etkiler (Büyüköztürk ve diğerleri, 2014).

Evren ve Örneklem: Yapılan araştırmanın evrenini Trabzon il merkezinde öğrenim gören 2, 3 ve 4 . sınıf öğrencileri oluşturmaktadır. Araştırmanın örneklemini ise Trabzon il merkezindeki üç okulda öğrenim gören ikinci sınıflardan 127, üçüncü sınıflardan 167 ve dördüncü sınıflardan 142 olmak üzere üç farklı okuldan toplam 436 öğrenci oluşturmaktadır. Araştırmanın örneklemi, olasılığa dayalı örnekleme içinde yer alan "basit olasılıklı (rastgele) örnekleme", yolu ile belirlenmiştir. Birinci sınıf öğrencileri yazma becerileri kazanımlarında yeterli olgunluğa erişmedikleri için çalışmaya dahil edilmemiştir. Ayrıca birinci sınıf öğrencilerinin okuma yazmaya bazı sınıflarda yılın ikinci döneminde geçtiği düşünüldüğünden araştırma 2. 3. ve 4. sınıf öğrencileriyle yürütülmüştür.

Veri Toplama Araçları: Araştırmada veri toplamak amacıyla "Yazılı Anlatımı Değerlendirme İçin Dereceli Puanlama Anahtarı" ve "Çok Boyutlu Okunaklılık Ölçeği" kullanılmıştır. Derecelendirilmiş puanlama anahtarı, Erdoğan (2012) tarafından geliştirilmiştir. Geliştirilen dereceli puanlama anahtarının bazı maddeleri gözden geçirilmiş, düzenlenmiş ve üç alan uzmanının görüşleri alınmıştır. Böylece dereceli puanlama anahtarının kapsam geçerliği sağlanarak dereceli puanlama anahtarına son şekli verilmiştir. Derecelendirilmiş puanlama anahtarında yer alan maddeler, 2. 3. ve 4. sınıf öğrencilerinin yazılı anlatım çalışmalarını değerlendirebilecek nitelikte yeniden düzenlenmiştir. Derecelendirilmiş puanlama anahtarında toplam 12 madde yer almaktadır ve bu maddeler "1, 2, 3" şeklinde puanlanmaktadır. Ölçekten alınabilecek en yüksek puan 36'dır. Buna göre 12-20 puan 
aralığı düşük, 21-28 puan aralığı orta ve 29-36 puan aralığı ise iyi düzey olarak belirlenmiştir.

Öğrencilerin yazı okunaklılığının ölçülmesi için Yıldız ve Ateş (2010) tarafından geliştirilen "Çok Boyutlu Okunaklılık Ölçeği"; eğim, boşluk, ebat, biçim ve çizgi takibi olmak üzere toplam 5 maddeden oluşmaktadır. Ölçekte boyutlar " Tamamen Yeterli”, “Orta Düzeyde Yeterli” ve “Hiç Yeterli Değil’’ şeklinde derecelendirilmiştir. Ölçekte alınabilecek maksimum puan 15'tir. Araştırmada uygulanan ölçeğin güvenirlik düzeyini belirlemek için Cronbach Alfa katsayısı hesaplanmıştır. Ölçeğin Cronbach's Alpha değeri 0,763 olarak belirlenmiştir.

Verilerin Toplanması: Veriler, toplam üç ilkokulda toplanmıştır. Bunun için birer hafta arayla okullara gidilmiştir. Araştırmada toplam 436 öğrencinin okunaklılık ve yazılı anlatım çalışmaları incelenmiştir. Okunaklılık çalışmasına katılan bütün öğrencilere beş dakikalık bir süre verilmiştir. Her öğrenciye okunaklılık çalışması için önceden hazırlanan metinler verilmiştir. Öğrencilerden bu metinlere bakarak metinleri kendilerine dağıtılan çalışma kâğıdına yazmaları istenmiştir. Metinler hazırlanırken öğrencilerin sınıf bazında bir dakikada yazabileceği ortalama harf sayısı göz önünde bulundurulmuştur. Bunun dışında metinlerdeki kelimelerin açık ve anlaşılır olmasına da dikkat edilmiştir.

Yazılı anlatım çalışması için ise öğrencilere farklı konular (mutlu oldukları bir günü, unutamadıkları bir anıyı, en sevdikleri oyuncağı, hayvanı, spor dalını vb.) sunulmuş ve bu konuları anlatan ya da kendilerinin belirledikleri bir konu ile ilgili öğrencilerden bir yazı yazmaları istenmiştir. Öğrencilerden öncelikle kendilerine sunulan 
konulardan birisini seçmeleri istenmiştir. Konu seçiminde sınıf seviyeleri göz önünde bulundurularak konular çeşitlendirilmiş, bu sayede öğrencilerin rahatça yazı yazabilmeleri sağlanmıştır. Öğrencilere yazılı anlatım çalışması için yeterli süre verilmiştir.

Verilerin Analizi: Çalışmada elde edilen veriler, araştırmacının dışında üç sınıf öğretmeni tarafından da değerlendirilmiştir. Araştırmada ilk olarak verilerin aritmetik ortalama, standart sapma ve frekansları hesaplanmıştır. Öğrencilerin yazma becerilerinin sınıf değişkenine göre anlamlı fark gösterip göstermediği ise tek yönlü varyans analizi (ANOVA) ile belirlenmiştir.

Öğrencilerin yazılarının analizi için 3 alan uzmanı "Yazılı Anlatımı Değerlendirme İçin Dereceli Puanlama Anahtarı"nı kullanarak yazıları ayrı ayrı analiz etmiştir. Analizin ardından puanlayıcılar arası güvenirliğe bakılmıştır. Puanlayıcı sayısı ikiden fazla olduğundan Kendall'ın uyum katsayısı kullanılmıştır. Kendall'ın uyum katsayısı $\mathrm{W}=.82$ olarak hesaplanmıştır. Bu sonuç, puanlayıcılar arasında yüksek düzeyde uyum olduğunu ortaya koymaktadır.

\section{Bulgular ve Yorum}

\section{Birinci Araştırma Sorusuna İlişkin Bulgular}

Öğrencilerin yazı okunaklılığını ölçmek için önceden hazırlanan metinler öğrencilere dağıtılmış ve öğrencilerden o metinlere bakarak yazmaları istenmiştir. Öğrencilerin yazı okunaklılığına ait puanların aritmetik ortalama ve standart sapmaları Tablo 1' de verilmiştir.

Tablo 1. Öğrencilerin Yazı Okunaklılığına İlişkin Puanları 
YYÜ Ĕ̆itim Fakültesi Dergisi (YYU Journal Of EducationFaculty),2017; 14(1):1003-1024,http://efdergi.yyu.edu.tr

\begin{tabular}{ccccc}
\hline & Sinif & $\mathrm{N}$ & $\bar{x}$ & Ss \\
\hline \multirow{3}{*}{ Okunaklilik } & 2. sinif & 127 & 9,59 & 1,96 \\
\cline { 2 - 5 } & 3. sinif & 167 & 10,13 & 2,02 \\
\cline { 2 - 5 } & 4. sinif & 140 & 10,13 & 2,14 \\
\hline Toplam & & 434 & 9,97 & 2,05
\end{tabular}

Öğrencilerin yazı okunaklılığına ilişkin puanları incelendiğinde ortalama puanın 9,97 ve standart sapmanın da 2,05 olduğu görülmektedir. Yıldız ve Ateş’e (2010) ait olan "Çok Boyutlu Okunaklılık Ölçeğì"nde “8,4-11,7” arasındaki değerler orta düzeyde okunaklı olarak ifade edilmiştir. Buna göre öğrencilerin yazı okunaklılı̆̆ının orta düzeyde okunaklı seviyesinde olduğu elde edilen bulgulara göre söylenebilir. Ayrıca 2. sınıf öğrencilerinin ortalama puanı 3 ve 4. sınıf öğrencilerinin gerisinde kaldığ 1 görülmektedir.

Öğrencilerin yazı okunaklılı̆ğ frekans dağılımlarına ilişkin sonuçlar Tablo 2' de verilmiştir.

Tablo 2. Öğrencilerin Yazı Okunaklılığına İlişkin Frekans Dağılımları

Okunaklı Orta Düzeyde Okunaklı_ Okunaklı Değil

\begin{tabular}{cccc}
\hline 2. Sinif & 52 & 34 & 41 \\
\hline 3. Sinif & 27 & 103 & 37 \\
\hline 4. Sinif & 43 & 70 & 27 \\
\hline Toplam & 122 & 207 & 105 \\
\hline
\end{tabular}

Tablo 2'ye göre toplam 434 öğrencinin yazıları okunaklılık açısından incelenmiştir. Elde edilen bulgulardan bu öğrencilerin 115'inin yazısının okunaklı olmadığı sonucuna ulaşılmaktadır. Buradan hareketle yine her dört öğrenciden birisinin yazma becerilerinde 
yetersizlik olduğu, yazı okunaklılığının beklenenin altında olduğu sonucuna varılabilir. Öğrencilerin okunaklılık çalışmasında harflerin aynısını görmelerine rağmen doğru yazamamaları dikkat çeken bir durumdur.

\section{İkinci Araştırma Sorusuna İliş̧kin Bulgular}

Öğrencilerin yazılı anlatım becerilerini ölçmek için daha önceden hazırlanan çeşitli konular öğrencilere sunulmuş ve öğrencilerden seçtikleri bir konu ile ilgili yazı yazmaları istenmiştir. Öğrencilerin yazılı anlatım becerilerine ilişkin puanların aritmetik ortalama ve standart sapmaları Tablo 3' de verilmiştir.

Tablo 3. Öğrencilerin Yazılı Anlatım Becerilerine İlişkin Puanları

\begin{tabular}{ccccc}
\hline & Sinif & $\mathrm{N}$ & $\bar{x}$ & Ss \\
\hline \multirow{3}{*}{ Yazilı Anlatım } & 2. sinif & 127 & 26,61 & 6,13 \\
\cline { 2 - 5 } & & & & 5,78 \\
\cline { 2 - 5 } & 3. sinif & 167 & 27,25 & 4,09 \\
\hline Toplam & & 142 & 30,35 & 5,62 \\
\hline
\end{tabular}

Yazılı anlatım çalışmasına ilişkin veriler incelendiğinde, ortalama puanın 28,07 ve standart sapmanın ise 5,62 olduğu görülmektedir. Ölçekten alınabilecek puanlar incelendiğinde 21-28 puan aralığının orta düzey ve 29-36 puan aralığının ise iyi düzey olduğu görülmektedir. Buna göre 2. ve 3. sınıf öğrencilerinin yazılı anlatım becerilerinin orta düzey, 4. sınıf öğrencilerinin yazılı anlatım becerilerinin ise iyi düzeyde olduğu söylenebilir. Bununla birlikte öğrencilerin yazılı anlatım puanının, sınıf seviyesinin artmasıyla doğru orantılı olarak arttığı görülmektedir.

Öğrencilerin yazılı anlatım becerilerinde elde edilen puanlara ilişkin sonuçlar Tablo 4' de verilmiştir. 
Tablo 4. Öğrencilerin Yazılı Anlatım Becerilerine İlişkin Frekans Dağılımları

\begin{tabular}{cccc}
\hline & Iyi & Orta & Düşük \\
& $(29-36$ puan $)$ & $(21-28$ puan $)$ & $(12-20$ puan $)$ \\
\hline 2. Sinıf & 79 & 48 & 20 \\
\hline 3. Sinıf & 70 & 68 & 19 \\
\hline 4. Sinıf & 101 & 27 & 4 \\
\hline Toplam & 250 & 143 & 43 \\
\hline
\end{tabular}

Öğrencilerin yazılı anlatım becerilerine ilişkin tablo incelendiğinde, öğrencilerin \%9,8'inin yazılı anlatım becerilerinde düşük seviyede olduğu görülmektedir. Yazılı anlatım çalışmasına göre en yüksek başarıyı 4. sınıf öğrencileri göstermiştir. Onları sırasıyla 2. ve 3. sınıf öğrencileri takip etmiştir. 4. sınıf öğrencilerinin büyük çoğunluğu iyi seviyede yazılı anlatım becerilerine sahip olduğu görülmektedir.

\section{Üçüncü Araştırma Sorusuna İlişsin Bulgular}

Öğrencilerin yazı okunaklılığına ilişkin aldıkları puanlar arasında sınıflara göre anlamlı bir fark olup olmadığına ilişkin sonuçlar Tablo 5’ de sunulmuştur.

Tablo 5. Öğrencilerin Yazı Okunaklılığı Çalışmalarının Sınıflara Göre ANOVA Sonuçları

\begin{tabular}{ccccc}
\hline Varyansın Kaynağ1 & Kareler Toplamı & sd & Kareler Ortalaması & F \\
\hline Gruplararası & 26,172 & 2 & 13,086 & 3,12 \\
\hline Gruplariçi & 1803,496 & 431 & 4,184 \\
\hline
\end{tabular}




Toplam $1829,668 \quad 433$

Tablo 5'de öğrencilerin yazı okunaklılı̆̆ının sınıflara göre dağılımı incelendiğinde sınıflar arası anlamlı bir farklılığın $(\mathrm{p}<, 05)$ olduğu söylenebilir. Farkın hangi sınıflar arasında olduğunu belirlemek için yapılan Tukey testi sonuçlarına göre ikili karşılaştırmalarda $\mathrm{p}$ değerinin (,045) ,05 düzeyine çok yakın olması nedeniyle öğrencilerin okunaklılık becerilerinin sınıf düzeyine göre değişmediği söylenebilir.

\section{Dördüncü Araştırma Sorusuna İlişskin Bulgular}

Öğrencilerin yazılı anlatım çalışmalarında aldıkları puanlar arasında sınıflara göre anlamlı bir fark olup olmadığına ilişkin sonuçlar Tablo 6'da sunulmuştur.

Tablo 6. Öğrencilerin Yazılı Anlatım Çalışmalarının Sınıflara Göre ANOVA Sonuçları

\begin{tabular}{ccccc}
\hline Varyansın Kaynağı & Kareler Toplamı & sd & Kareler Ortalaması & F \\
\hline Gruplararası & 1118,952 & 2 & 559,476 & 19,14 \\
Gruplariçi & 12653,844 & 433 & 29,224 & \\
Toplam & 13772,796 & 435 & & \\
\hline
\end{tabular}

Yukarıdaki Tablo 6 incelendiğinde sınıflar arası farklılığın anlamlı olduğu $(p<, 05)$ söylenebilir. Farkın hangi sınıflar arasında olduğunu belirlemek için yapılan Tukey testi sonuçlarına göre 4. sınıf öğrencilerinin yazılı anlatım becerilerinin 2. ve 3. sınıf öğrencilerinden anlamlı derecede yüksek olduğu görülmektedir. Bu sonuçtan hareketle yazılı anlatım becerilerinin 4. sınıfta artış gösterdiği ve 3. sınıfta anlamlı bir artış göstermediği söylenebilir. 


\section{Tartışma}

$\mathrm{Bu}$ araştırmanın amacı, ilkokul 2, 3 ve 4. sınıf öğrencilerinin yazma becerilerini okunaklılık ve yazılı anlatım açısından incelemektir. Araştırmadan elde edilen sonuçlar, 436 öğrencinin 115'inin yazısının okunaklı olmadığını ortaya koymaktadır. Başka bir ifade ile her dört öğrenciden birinin yazısının okunaklı düzeyde olmadığı görülmektedir. Okunaklılık, yazma öğrenme sürecini etkileyen önemli bir değişkendir. Ayrıca okunaklı bir şekilde yazılan el yazısı, bir öğrencinin okul hayatı boyunca kullanacağı temel bir beceridir (Towle 1978). Yapılan araştırmada öğrencilerin bir kısmının okunaklı yazılar yazmamaları, bitişik eğik el yazısı öğretiminde yeterli sayıda çalışmaya yer verilmemesinden, öğrencilerin yazılarına yönelik yeterli dönüt verilmemesinden veya öğretmenlerin bu süreçte iyi model olmamalarından kaynaklanabilir. Araştırmadan elde edilen bu bulgu bazı çalışmaların sonuçlarıyla örtüşmektedir (Rosenblum, Weiss ve Parush, 2004; Ziviani ve Watson-Will, 1998). Yıldız ve Ateş (2010) tarafindan yapılan çalışmada okumayı farklı yöntemlerle öğrenen ilkokul 3. sınıf öğrencilerinin yarısından fazlasının yazısının okunaklı olmadığı sonucuna ulaşılmıştır. Yıldız, Yıldırım ve Ateş'in (2009) sınıf öğretmenlerinin sınıf tahtasına yazdıkları bitişik eğik yazıları değerlendirdikleri araştırmanın sonucunda ise öğretmenlerin yazılarının öğrencilere model olamayacak nitelikte olduğunu ortaya koymuşlardır. Bununla birlikte öğretmenlerin yazı yetersizliği olan öğrencilere yeterince ilgi gösterme ve yazma çalışmalarına yeterli zaman ayırma gibi hususlarda sorun yaşamaları da öğrencilerin okunaklı yazılar yazamamalarının nedeni olabilir. Oysaki yazı okunaklılığında bekleneni karşılayamama, çocuğun yazma performansını ve yazmaya olan ilgisini azaltabilir (Tok, 2016) ve öğrencilerin yazma motivasyonlarını düşürebilir (Graham, 1997). 
Öğrencilerin okunaklı ve düzgün yazılar yazabilmeleri için sinıflarda her gün yazı çalı̧̧maları yapılmalı ve bu çalışmalarda çocuğun sırada doğru oturmasına, kolunu uygun şekilde masaya yerleştirmesine ve kalemi doğru tutmasına dikkat edilmelidir (Akyol, 2013). Okunaklı bir yazı yazılabilmesi için son derece önemli olan bu etkenler ilkokul birinci sınıftan itibaren öğretmenler tarafından dikkate alınmalıdır. Köksal'a (1999) göre ilkokul birinci sınıftan itibaren yazma öğretiminde, öğrencilere kalem tutma, kalemle istenilen çizgiyi çizme, düzgün, okunaklı ve kurallarına uygun yazı yazma becerileri uzun tekrarlardan sonra kazandırılabilir. Graham, Harris ve Fink, (2000) yaptıkları deneysel bir çalışmada öğrencilere 6 aylık bir eğitim vermişlerdir. Bu eğitimin sonucunda, çocukların daha okunaklı yazılar yazdıkları görülmüştür. Yazma becerilerinin gelişimi ile ilgili yapılan birçok çalışma da öğretmenlerin süreçte aktif rol almaları ile olumlu sonuçlar alındığını ortaya koymaktadır (Maden ve Durukan; 2010; Demirkol, 2012; Yıldız, 2013; Lupeac, 2014). Bu bulgular, el yazısı güçlüklerini önlemede ve eğitim sürecinde öğretmen faktörünün ne denli önemli olduğunu vurgulamaktadır.

Araştırmadan elde edilen bir başka bulgu, öğrencilerin büyük bir çoğunluğunun yazılı anlatım becerilerinde orta seviyede oldukları yönündedir. Başka bir ifadeyle 2. ve 3. sınıf öğrencilerinin yazılı anlatım becerilerinin orta düzey, 4. sınıf öğrencilerinin yazılı anlatım becerilerinin ise iyi düzeyde olduğu ortaya konmuştur. Öğrencilerin yazmanın içerik boyutunda orta seviyede olmaları; bol okuma çalışmaları yapmalarıyla, öğretmenlerin yazılı anlatım sürecine olan tutumlarıyla, derslerde yapılan farklı etkinliklerle, kullanılan yöntem ve tekniklerin öğrenci seviyesine ve ilgisine uygun olmasıyla ilgili olabilir. Öğrencilerin yazılı anlatım ifadelerinin gelişmesinde, sınıfta yapılan farklı yazma etkinliklerinin, öğrencilerin ilgisini çeken yöntem ve tekniklerin rol oynadığını ortaya koyan birçok araştırma vardır (Arıc1 ve Ungan, 2008; Erdoğan, 2012; Feuer, 2011; Maden ve Durukan, 2010; Pardlow, 
2003; Temizkan, 2011; Demir, 2012). Bu araştırma sonuçları yazılı anlatım becerilerinin geliştirilmesinde öğretmenin rolünü de ortaya koymaktadır. Özdemir’e (2014) göre bu süreçte öğretmenlerin amacı öğrencilerin yazmaya karşı istekli, yazılı anlatım becerilerini kendi kendilerine değerlendirebilen ve gerekli düzeltmeleri bağımsız olarak yapabilen bireyler yetiştirmek olmalıdır. Buradan hareketle ilkokul öğrencilerinin yazılı anlatım becerilerinin bir bütün olarak gelişmesi için birinci sınıftan itibaren yazmaya yönelik ilgileri ve başarıları dikkate alınarak bir öğretim süreci planlanmalıdır.

Araştırmada elde edilen sonuç, öğrencilerin yazı okunaklılığının sınıf seviyesine göre gelişim göstermediğini ve orta düzeyde kaldığını göstermektedir. Öğrencilerin yazılarının sınıf seviyesi arttıkça gelişim göstermemesinde, okunaklılık gelişiminin uzun sürede gerçekleşmesi etkili olabilir. Graham'a (2010) göre okunaklı bir yazı gelişimi için zaman ve öğretmenlerin bu süreçteki çabaları son derece önemlidir. Buradan hareketle üst sınıflara geçtikçe yazı okunaklılığının gelişmemesi, öğretmenlerin yazı okunaklılı̆̆ı için harcadıkları zamanın ve verdikleri eğitimin yeterli olmamasından kaynaklanabilir. Oysaki doğru, akıcı ve okunaklı bir yazı alışkanlığının edinimi için öğrencilere verilen yazma eğitimin niteliği son derece önemlidir (Daly, Kelley ve Krauss, 2003). Çünkü el yazısı ve akademik başarı arasında çok önemli bir ilişki vardır. Bu nedenle öğretmenlerin yazma öğretiminin önemi hakkında yeterli bilgi ve yeterliliğe sahip olması gerekir (Zachry ve Doan, 2016). Amerikan Mesleki Terapi Derneği (2002), bu alanda yeterli bilgi ve deneyime sahip olmayan öğretmenler için gerekli hizmet içi eğitim verilmesinde mesleki terapistlerin (yazma uzmanlarının) yer alması gerektiğini savunmaktadır. Mesleki terapistlerden (yazma uzmanlarından) alınan eğitim ile öğretmenler, yazma öğretim sürecini daha nitelikli gerçekleştirebilir ve böylece daha akıcı ve okunaklı yazı gelişimi için öğrencilerle doğru çalışmalar yapabilir (Zachry ve Doan, 2016). 
Araştırmadan elde edilen bulgular yazı okunaklılığı becerilerinde sınıflar arasında anlamlı bir farkın olmadığını ortaya koymaktadır. Araştırmadan elde edilen bu bulgu bazı araştırma sonuçları ile tutarlılık göstermemektedir. (Erden, Kurdoğlu ve Uslu, 2002; Klein ve Taub, 2005; Sweedler-Brown, 1992). Bununla birlikte Mojet de (1991) yazıların okunaklılık düzeylerinin dördüncü sınıf düzeyinde şekillendiğini ifade etmiştir. Erdoğan (2012) tarafından yapılan bir araştırma sonucu ise bu çalışma ile paralellik göstermektedir. Erdoğan (2012) yaptığı araştırmada öğrencilerin yazılarının okunaklılık açısından gelişim göstermediğini ortaya koymuştur.

Araştırmadan elde edilen bir başka bulgu ise, yazılı anlatım becerilerinde sınıflar arasında anlamlı bir farklılığın olduğu yönündedir. Yapılan araştırmada sınıf seviyesi arttıkça öğrencilerin daha nitelikli yazılar yazmaları, onların düşünme, yorumlama, sorgulama vb. zihinsel becerilerde kendilerini daha iyi ifade etmelerinden kaynaklanabilir. Graham'a (2010) göre öğrenciler ilk sınıflarda yazı yazarken daha çok yazmanın biçimsel yönüyle, sınıf seviyesi ilerledikçe ise içerik yönü ile ilgilenirler. Çünkü harflerin biçimi, boyutu, eğimini iyice öğrenen ve pekiştiren öğrenci, düşüncelerin planlanması ve düzenlenmesi üzerine zaman harcar. Graham ve Harris, (2005) yazma başarısı iyi olan öğrencilerin düşüncelerin üretimi ve düzenlenmesi üzerine yoğunlaştıklarını, başarısız öğrencilerin ise sadece okunaklılık ile ilgilendiklerini ifade etmişlerdir. Buradan hareketle hem okunaklı bir yazı hem de nitelikli bir yazı öğretimi için daha eğlenceli ve destekleyici bir sınıf ortamı son derece önemlidir. $\mathrm{Bu}$ açıdan ilk sınıflardan itibaren öğrencilerin kendi fikirlerini özgürce yazmalarına imkan sunulmalı, ilgilerine yönelik yazma çalışmalarına yer verilmeli ve her türlü yazma girişimleri takdir edilmelidir (Richards ve Lassonde, 2011). 
Araştırmanın sonuçlarına genel olarak bakıldığında okunaklılık ve yazılı anlatım çalışmaları incelenen ilkokul 2, 3 ve 4. sınıf öğrencilerin yazı okunaklılığında istenilen seviyede olmadıkları belirlenmiştir. Bununla birlikte 2. ve 3. sınıflarda orta düzey, 4 . sınıflarda ise iyi düzeyde yazılı anlatım becerilerine sahip oldukları söylenebilir. Araştırmada elde edilen bu sonuçlar 1şı̆̆ında şu öneriler getirilebilir:

1. Yazma becerilerinin geliştirilmesi için özellikle okulda, öğretmen denetiminde gerekli ve yeterli yazma etkinlikleri (dikte yapma, özet çıkarma, günlük yazma vb.) yapilmalidir.

2. Öğrencilerin okunaklılık becerilerinin geliştirilmesi için öğretmenler tarafından gerekli ve yeterli yazma çalışmaları yapılmalıdır.

3. Yazma becerileri konusunun önemi konusunda öğretmenler bilgilendirilmeli ve öğretmenlere hizmet içi eğitim verilmelidir.

\section{Makalenin Bilimdeki Konumu (Yeri)}

Sınıf Öğretmenliği Anabilim Dalı

\section{Makalenin Bilimdeki Özgünlüğü}

Yazma çalışmalarıyla ilgili literatür incelendiğinde yazma becerisi üzerine daha çok deneysel çalışmalar yapıldığı görülmektedir. Oysaki ilkokul öğrencilerinin yazma becerilerini bütünüyle ele alan çalışmaların sayısı ise oldukça azdır. Bu çalışma, öğrencilerin sınıf seviyelerine göre yazma becerilerinin ne düzeyde olduğunu ortaya koyması bakımından önem arz etmektedir. Bununla birlikte, yazma becerisinin hem okunaklılık hem de yazılı anlatım açısından incelenmesi ve sınıflar arasındaki gelişimin belirlemesi çalışmaya özgünlük katmaktadır. 436 öğrenci ile yürütülen bu araştırma sonuçlarının, diğer araştırmacılara yol göstereceği düşünülmektedir. 


\section{Kaynakça}

Akyol, H. (2013). Türkçe ilk okuma yazma öğretimi. Ankara: Pegem Akademi.

Albertson, L. R. ve Billingsley, F. F. (2000). Using strategy instruction and self-regulation to improve gifted students' creative writing. Journal of Advanced Academics, 12 (2), 90101.

American Occupational Therapy Association. (2002). Handwriting.

Archibald, M. (2010). Perceptions of diverse first-grade learners of their writing instruction and growth as writers. (Yayımlanmamış doktora tezi), Walden University.

Arıcı, A. F. ve Ungan, S. (2008). Konu seçiminin yazma becerisine etkisi. Çağdaş Ĕ̆gitim Dergisi, 33 (357), 19-24.

Bearne, E. (2002). Making progress in writing. London: Routledge Falmer.

Brailsford, A.ve Stead, T. (2007). Literacy place for the early years. Scholastic Canada Ltd.

Büyüköztürk, Ş., Çakmak, E. K., Akgün, Ö. E., Karadeniz, Ş. ve Demirel, F. (2014). Bilimsel araştırma yöntemleri. Ankara: Pegem Akademi.

Calp, M. (2013). Yazma problemi olan bir öğrenciye bitişik eğik yazı öğretimi. International Journal of Educational Research, 4 (1), 1-28.

Chien, S. C. (2010). Enhancing english composition teachers' awareness of their students' writing strategy use. The Asia Pacific Education Researcher, 19 (3), 417-438.

Daly, C. J., Kelley, G. T., ve Krauss, A. (2003). Relationship between visual-motor integration and handwriting skills of children in kindergarten: A modified replication study. American Journal of Occupational Therapy, 57(4), 459-462.

Demir, T. (2012). Türkçe eğitiminde yaratıcı yazma becerisini geliştirme ve küçürek öykü. Mustafa Kemal Üniversitesi Sosyal Bilimler Enstitüsü Dergisi, 9 (19), 343-357.

Demirel, Ö. ve Şahinel, M. (2006). Türkçe öğretimi. Ankara: Pegem Akademi. 
Demirkol, N. (2012). 2. sınıfa devam eden iki öğrencinin yazım hatalarının düzeltilmesi üzerine bir durum çalışması. Yayımlanmamış yüksek lisans tezi, Necmettin Erbakan Üniversitesi, Konya.

Erden, G., Kurdoğlu, F. ve Uslu, R. (2002). İlköğretim okullarına devam eden Türk çocuklarının sınıf düzeylerine göre okuma hızı ve yazım hataları normlarının geliştirilmesi. Türk Psikiyatri Dergisi, 13 (1), 5-13.

Erdoğan, Ö. (2012). Süreç temelli yaratıcı yazma uygulamalarının yazılı anlatım becerisine ve yazmaya ilişkin tutuma etkisi. (Yayımlanmamış doktora tezi). Hacettepe Üniversitesi, Sosyal Bilimler Enstitüsü, Ankara.

Erdoğan, T. (2012). İlköğretim birinci sınıf öğrencilerinin bitişik eğik yazı yazma gelişimlerinin incelenmesi, Eğitim ve Bilim, 37(165), 93-103.

Feuer, A. (2011). Developing foreign language skills, competence and identity through a collaborative creative writing project. Language, Culture and Curriculum, 24 (2), 125-139.

Flowers, L. ve Hayes, J. R. (1981). A cognitive process theory of writing. College Composition and Communication, 32 (4), 928-950.

Fountas, I. ve Pinnell, S. (2009). Prompting Guide: A tool for literacy teachers. fountas. Portsmouth, New Hampshire: Heinemann.

Graham, S. (2010). Want to improve children's writing? Don't neglect their handwriting. American Educator. 20-40.

Graham, S. (1997). Executive control in the revising of students with learning and writing difficulties. Journal of Educational Psychology, 89 (2), 223-234.

Graham, S., Berninger, V. W. ve Weintraub, N. (1998). The relationship between handwriting style and speed and legibility. The Journal of Educational Research, 91(5), 290-297. 
Graham, S.ve Miller, L. (1980). Handwriting research and practice: A unified approach. Focus on Exceptional Children, 13, 1-16.

Graham, S., Harris, K. R. ve Fink, B. (2000). Extra handwriting instruction: Prevent writing difficulties right from the start. Teaching Exepcional Children, 33 (2), 88-91.

Karasar, N. (2014). Bilimsel araştırma yöntemi. Ankara: Nobel Akademi.

Klein, J.veTaub, D. (2005). The effect of variations in handwriting and print on evaluation of student essays. Assessing Writing, 10(2), 134-148.

Köksal, K. (1999). Okuma yazmanın öğretimi. Ankara: Pegem Akademi.

Kuvanç, K. E. B. (2008). Yaratıcı yazma tekniklerinin öğrencilerin türkçe dersine ilişkin tutumlarına ve türkçe dersindeki başarılarına etkisi. (Yayımlanmamış yüksek lisans tezi), Dokuz Eylül Üniversitesi, İzmir.

Lupeac, V. (2014). Physical education fort the correction of dysgraphia in primary school pupils. Palestrica of the Third Millennium-Civilization and Sport, 15 (2), 122-126.

Maden, S. ve Durukan, E. (2010). İstasyon tekniğinin yaratıcı yazma becerisi kazandırmaya ve derse karşı tutuma etkisi. Türklük Bilimi Araştırmaları Dergisi, 15 (28), 299-312.

Moore, N. S. (2009). The effects of being a reader and of observing readers on fifth grade students' argumentative writing. (Yayımlanmamış doktora tezi), University of Delaware.

Mojet, J. (1991). Characteristics of the developing handwriting skill in elementary education. In J. Wann, A. Wing, N. Sovik (Edt.), Development of graphic skills: Research, perspectives and educational implications (53-75). London: Academic Press.

Olinghouse, N. G. ve Santangelo, T. (2010). Assessing the writing of struggling learners. Focus On Exceptional Children, 43 (4), 1-27. 
Özdemir, B. (2014). Analitik yazma ve değerlendirme modelinin Türkçe öğretmeni adaylarının yazma becerilerine ve yazma tutumlarına etkisi. (Yayımlanmamış doktora tezi), Gazi Üniversitesi, Ankara.

Pardlow, D. K. (2003). Flight to flatland: A descriptive study of using creative writing pedagogy to improve the teaching of first year english composition. (Yayımlanmamış doktora tezi). Indiana University of Pennsylvania.

Prior, P. (2006). A sociocultural theory of writing. C.A. MacArthur, S.Graham ve J. Fitzgerald (Ed.), Handbook of writing research. New York: Guilford Press.

Richards, J. C. ve Lassonde, C. A. (2011). Writing strategies for all primary students: Scaffolding independent writing, Jossey-Bass Teacher.

Rosenblum, S., Weiss, P. L. ve Parush, S. (2004). Handwriting evaluation for developmental dysgraphia: Process versus product. Reading and writing: An Interdisciplinary Journal, 17, 433-458.

Sweedler-Brown, C. O. (1992). The effect of training on the appearance bias of holistic essay graders. Journal of Researchand Development in Education, 26(1), 24- 29.

Temizkan, M. (2011). Yaratıcı yazma etkinliklerinin öykü yazma becerisi üzerindeki etkisi. Kuram ve Uygulamada Ĕ̌itim Bilimleri, 11 (2), 919-940.

Thornton, A. (2010). Teachers' self-perception of their writing and their teaching of writing. Doctoral of dissertation, Capella University.

Tok, R. (2016). İlkokul 2. 3. ve 4. sınıf öğrencilerinin yazma becerilerinin incelenmesi, (Yayımlanmamış yüksek lisans tezi). Karadeniz Teknik Üniversitesi, Trabzon.

Towle, M. (1978). Assessment and remediation of handwriting deficits for children with learning disabilities. Journal of Learning Diabilities, 11(6), 43-51. 
Tseng, M. H. ve Chow, S. M. K. (2000). Perceptual-motor function of school-age children with slow handwriting speed. The American Journal of Occupational Therapy, 54(1), 83-88.

Ünalan, Ş. (2001). Türkçe ögrretimi. Ankara: Nobel Yayın Dağıtım.

Wang, A. Y. (2012). Exploring the relationship of creative thinking to reading and writing. Thinking Skills and Creativity, 7 (1), 38-47.

Yıldız, M. (2013). Yazma güçlüğü olan bir ilkokul 2. sınıf öğrencisinin el yazısı okunaklılığının geliştirilmesi: Eylem araştırması. Uşak Üniversitesi Sosyal Bilimler Dergisi, 16, 281-310.

Yıldız, M. ve Ateş, S. (2010). İlk okuma yazmayı farklı yöntemlerle öğrenen ilköğretim 3. sınıf öğrencilerinin yazılarının okunaklılık ve yazım hataları bakımından karşılaştırılması. Türkiye Sosyal Araştırmalar Dergisi, 1, 11-30.

Yıldız, M., Yıldırım, K. ve Ateş, S. (2009). Sınıf öğretmenlerinin sınıf tahtasına yazdıkları yazıların okunaklılık bakımından öğrencilere model olmadaki uygunluğu. Uluslararası Insan Bilimleri Dergisi, 6 (2), 75-88.

Zachry, A. H. ve Doan, A. P. (2016). A comparison of print and cursive handwriting in fifth and sixth grade students: A pilot study. The Open Journal of OccupationalTherapy. $4(2), 1-9$.

Zampardo, K. M. (2008). An examination of the impact of teacher modeling on young children's writing. Doctoral of dissertation, Oakland University, Michigan.

Ziviani, J. ve Watson-Will, A. (1998). Writing speed and legibility of 7-14-year-old school students using modern cursive script, Australian Occupational Therapy Journal, 45, 59-64. 